\title{
Spatio-temporal segregation and size distribution of fish assemblages as related to non-native species occurrence in the middle rio Doce Valley, MG, Brazil
}

\author{
Henrique Corrêa Giacomini ${ }^{1}$, Dilermando Pereira Lima Jr. ${ }^{2}$, Anderson Oliveira Latini ${ }^{3}$ \\ and Helder Mateus Viana Espírito-Santo ${ }^{4}$
}

The lakes in the middle rio Doce Valley (MG) are suffering impacts due to the introduction of invasive fish species, mainly piscivorous species like red piranha Pygocentrus nattereri and peacock bass Cichla kelberi. Fishes were collected in bimonthly samples conducted at ten lakes along a year. The present study showed that the composition of native fish assemblages is significantly related to the presence and type of non-native species. Fish species distribution among lakes can be explained by differences in species body size: smaller native species are less concentrated in lakes with invasive piscivores, which is in accordance with the hypothesis that they have greater susceptibility to predation by invaders. Another probable cause for this correlation is the proximity of lakes to the drainage system, which could explain both the non-native incidence and the turnover of native species composition. Furthermore, temporal variability in species composition was significantly higher in invaded lakes. This last factor may be linked to seasonal flood pulses, which carry immigrant fishes from streams in the vicinity. The metacommunity framework can bring insights for future studies in such spatially structured systems, and the approach should improve our understanding of processes underlying species composition as well as help direct conservation-focused management plans.

Os lagos do Vale do médio rio Doce (MG) têm sofrido impactos devido à introdução de espécies invasoras de peixes, principalmente de espécies piscívoras como a piranha Pygocentrus nattereri e o tucunaré Cichla kelberi. Peixes foram coletados em seis amostragens bimestrais durante um ano. O presente trabalho demonstrou que a composição das assembleias de peixes nativos está significativamente relacionada à presença e ao tipo de espécies não nativas. A distribuição de espécies entre os lagos pode ser explicada por diferenças no tamanho corporal: espécies nativas de menor porte tendem a estar menos concentradas em lagos com invasores piscívoros, o que está de acordo com a hipótese de que tais espécies têm maior susceptibilidade à predação pelos invasores. Outra provável causa para essa correlação é a proximidade dos lagos ao sistema de drenagem, o que pode explicar tanto a incidência de não nativos quanto a variação na composição de espécies nativas. Além disso, a variabilidade temporal na composição foi significativamente maior em lagos com não nativos. Esse último fator pode estar ligado a pulsos de inundação sazonais, que trazem imigrantes dos riachos adjacentes. A abordagem de metacomunidades pode trazer ideias para futuros estudos neste sistema espacialmente estruturado, devendo melhorar nosso conhecimento sobre os processos que determinam sua composição de espécies e ajudando a direcionar planos de manejo para sua conservação.

Key words: Species invasions, Beta diversity, Metacommunity, Body size, Predation.

\section{Introduction}

Invasive species are responsible for large environmental, economic and social impacts (Mack et al., 2000; Pimentel et al., 2001). The translocation and establishment of species around the world is the principal determinant of biotic homogenization, mainly in aquatic environments (Kolar \& Lodge, 2002; Rahel, 2002). Biotic homogenization is the process in which species invasions and extinctions of endemics increase the genetic and taxonomic similarity among communities, promoting ecological and evolutionary losses (Olden et al., 2004, 2006). The current flux of invasive species

${ }^{1}$ Departamento de Ecologia, Universidade Estadual Paulista “Júlio de Mesquita Filho", Campus de Rio Claro. Av. 24-A, 1515, 13506-900 Rio Claro, SP, Brazil. hgiacomini@gmail.com

${ }^{2}$ Programa de Pós-Graduação em Ecologia de Ecossistemas Aquáticos Continentais, Universidade Estadual de Maringá. Av. Colombo, 5790, 87020-900 Maringá, PR, Brazil.

${ }^{3}$ Programa Institucional de Bioengenharia - UFSJ. Cx. Postal 56, 35701-970 Sete Lagoas, MG, Brazil. aolatini@ufsj.edu.br ${ }^{4}$ Programa de Pós-Graduação em Ecologia, Instituto Nacional de Pesquisas da Amazônia. Av. André Araújo, 2936, Aleixo, Cx. Postal 478, 69060-001 Manaus, AM, Brazil. 
around the world contributes to the impoverishment of biodiversity, causing the exclusion of many native species by the growth and spreading of a few cosmopolitan and generalist species (Mckinney \& Lockwood, 1999; Olden, 2006).

The rio Doce basin, in southeastern Brazil, has a stretch with a lake system of huge ecological and historical importance (Vono \& Barbosa, 2001). Since the seventies, this lake system has been suffering successive species introductions, including fishes (Godinho, 1994) and invertebrates (De Marco, 1999). Among fishes, red piranha (Pygocentrus nattereri Kner, 1858) and peacock bass (Cichla kelberi Kullander \& Ferreira, 2006), the first natural from the Amazon, Paraguay and lower Paraná basins, and the second from Araguaia-Tocantins basin, are the two commonest non-native species in the region (Latini et al., 2004). These two species exhibit active predatory behavior, usually occupying top positions in food chains, and present strong parental care. These features were inferred as the main factors for their colonization success and the depletion of dozens of native populations in the lakes of the rio Doce basin where they occur (Latini \& Petrere, 2004).

In lentic freshwater environments, predation is recognized as one of the main factors regulating populations and structuring communities (Zaret, 1972; Thorp \& Cothran, 1984; Sih et al., 1985; Jackson et al., 2001), such as demonstrated by well-known cases of introductions of piscivorous fishes and their impacts (Zaret \& Paine, 1973; Kitchell et al., 1997; Latini \& Petrere, 2004). Basic knowledge of the trophic ecology of a species is crucial if some prediction is to be made on the potential impacts of its introduction on native communities (Fernando, 1991; Moyle \& Light, 1996). In natural food webs, body size plays a key role in vulnerability to predation, which is especially true for fish assemblages (Mittelbach \& Persson, 1998; Claessen et al., 2002). Small sized species are usually at lower trophic levels (Cohen et al., 1993, 2003), although such relationship may not be observed in some complex tropical fish assemblages (Layman et al., 2005). Furthermore, smallsized species tend to suffer higher predation pressures and by a larger number of predator species (Woodward \& Hildrew, 2002; Sinclair et al., 2003; Layman et al., 2005; Woodward et al., 2005). Such species are often the first impacted by an introduced predator, especially if they do not present appropriate anti-predatory features.

The influence of invasive species can go beyond the impoverishment of local communities. When different kinds of species are introduced unequally along the landscape, a series of regional effects can disturb processes at the metacommunity level (Holyoak et al., 2005a). Biased effects on functionally different species can generate or increase spatial segregation (McPeek, 1996; Wellborn et al., 1996). They also can lead assemblages to reach alternative stable states in structure, which in some cases cannot be reassembled to the original composition, even if the introduced species are completely eradicated (Morton \& Law, 1997). With changes in the spatial composition of assemblages, there is the potential for disrupting the flux of species among habitat patches when different species have different dispersal rates (Leibold et al., 2005).
Such effects can be more evident if the more affected species are those with high dispersal rates, and so more important in connecting the dynamics of interlinked communities (Leibold et al., 2005). On the other hand, the invasive species themselves are subjected to the constraints imposed by spatial structure and dispersal limitation. After initial events of introduction, they can spread across the landscape by means of a restricted set of dispersal corridors (Latini, 2005). So, the landscape connectivity is of great importance to determine the probability that a given lake be colonized by some invasive species. It may also be determinant to the native community structure itself, even before any invasion, as the maintenance of metapopulations in limited sized habitat patches depends ultimately on the colonization/extinction dynamics modulated by dispersal among them (Gotelli, 1991).

This study investigated spatial and temporal variation in native species composition in relation to the presence of different types of non-native species. Following the hypothesis that body size influences vulnerability to predation, we tested whether mean species body size correlated positively with the presence of invasive piscivores, and whether this bias can relate to significantly different native species compositions. We also tested whether the occurrence of non-natives was correlated with species richness and temporal variability in the composition of native fish assemblages, and at what extent it can be attributed to spatial or environmental constraints.

\section{Material and Methods}

\section{Study area}

The middle rio Doce Valley contains approximately 130 lakes, is one of the major lacustrine systems in Brazil (Tundisi \& De Meis, 1985), and stands among the highest priority sites for fish conservation in the State of Minas Gerais (Drummond et $a l ., 2005)$. The valley is located within the Atlantic Forest biome, which is considered the fourth most important biodiversity hotspot for conservation priority on the planet (Myers et al., 2000). The altitude varies from 236 to $535 \mathrm{~m}$ a.s.l. (Latini, 2005), and the climate is tropical semi-humid, with a rainy season in summer and a dry season lasting four to five months along winter (Nimer, 1989). The lakes studied herein are located in a region with commercial exploitation of Eucalyptus spp. in the eastern portion of the State of Minas Gerais, Brazil (Fig. 1), within the Municipality of Marliéria. This Eucalyptus exploitation area contains 24 lakes, from which 10 were chosen arbitrarily for this study. To the north of this area, is the Parque Estadual do Rio Doce (PERD; Rio Doce State Park), one of the few protected areas that still preserve Atlantic Forest vegetation in the interior of Brazil, containing 36.000 ha and approximately 42 lakes. Paradoxically, the impacted area where this study was conducted is currently more important for fish conservation, as almost $42 \%$ of its lakes are undamaged by fish introductions, compared with approximately $9 \%$ of lakes in the PERD area (Latini et al., 2004). For this reason, the Eucalyptus region was chosen for sampling lake fish communities in our study. 
The studied lakes have areas varying from 9.13 to 81.13 ha, presenting diverse shapes (Fig. 1). In their marginal regions, two types of environment can be easily identified: i) stretches covered by macrophyte beds and ii) stretches without macrophyte cover, with higher influence of the marginal forest cover. The first areas are characterized by having low depth and declivity, with little projection of the marginal trees upon the water surface, so they receive a higher solar irradiation. These factors allow the fixation of a dense tangle of macrophytes, mainly Eleocharis interstincta, but also Nymphaea elegans and N. populus, Salvinia auriculata, and Eichhornia crassipes. The areas without macrophytes have a more inclined bottom and an effective forest projection upon the water surface, which stays shady most of the day.

Six non-native fish species are found in seven of the 10 sampled lakes. Three of them deserve special attention because they are voracious piscivores: red piranha Pygocentrus nattereri and peacock bass Cichla kelberi, which are present in the lakes Águas Claras, Ariranha and Palmeirinha, and African catfish Clarias gariepinus (Burchell, 1822), present in the lake Palmeirinha. The first two can be considered invasive species (Lockwood et al., 2007), due to the already reported negative impacts on native communities (Latini \& Petrere, 2004) and the well known history of geographic spreading in the study region, while the others have been reported only more recently (Latini et al., 2004). The omnivorous singing catfish Hoplosternum littorale (Hancock, 1828) is present in all lakes above and also in lakes Poço Redondo, Romoalda and Timburé. The commercially important Nile tilapia Oreochromis niloticus (Linnaeus, 1758), is present in lake Crentes, and the Oscar Astronotus ocellatus (Agassiz, 1831) is present in lake Ariranha. For our analyses, lakes were classified in three groups (lake status): 1) lakes with only native species (Capim, Ferrugem and Nova), 2) lakes with non-piscivorous nonnative species (Crentes, Poço Redondo, Romoalda and Timburé), and 3) lakes with invasive piscivores (Águas Claras, Ariranha and Palmeirinha) (Fig. 1).

\section{Fish sample}

Fishes were sampled bimonthly from July 2002 through May 2003. For each sample at each lake, we deployed three sets of gill-nets, each composed by six gill-nets with different mesh sizes $(15,20,30,40,50$, and $60 \mathrm{~mm}$ between adjacent knots). Each net was $10 \mathrm{~m}$ long, except for the $60 \mathrm{~mm}$ mesh net, which had $20 \mathrm{~m}$. This mesh size interval is appropriate to provide a representative sample of the fish assemblage in these lakes (Latini \& Petrere, 2004). Each set of gill-nets was deployed parallel to the lake margin in arbitrarily chosen locations that included the different habitat physiognomies (areas with and without macrophyte beds, to guarantee a representative sample that included environmental heterogeneity). Nets were deployed for three hours, always overlapping the peak of fish activity, which occurs around 6 p.m. (Sunaga \& Verani, 1985). The fishes were put in plastic bags, and carried to the PERD laboratory for measurements. For each specimen collected, we determined the total weight (g) and the standard length ( $\mathrm{mm}$ ), except for some injured individuals (481, or $15 \%$ of total). To calculate the biomass of each species, we replaced the missing weight values by the species mean weight.

\section{Abiotic variables}

We took measures of five environmental variables: (i) lake area (ha); (ii) lake perimeter (m); (iii) oxygen concentration $\left(\mathrm{mg} . \mathrm{L}^{-1}\right)$; (iv) water turbidity (ntu "nephalometric turbidity units"); and (v) the nearest distance to the drainage system (m). The first two environmental variables were measured by means of satellite images (LANDSAT 7 ETM, 2000). They determine lake size and shape, which can influence habitat availability and heterogeneity, both important for species coexistence and diversity (Rosenzweig, 1995). The oxygen concentration is one indicator of the limnological status, and can be an important constraint to species performance in lakes (Wooton, 1992). The water turbidity is generally related to sediment and nutrient concentration, besides affecting the behavior of visually-oriented organisms, like most fish. The distance to the drainage system was taken along the shortest water course or valley paths linking the lake to the nearest stream, by looking at satellite images (LANDSAT 7 ETM, 2000). Such distance is supposed to have influences on the metacommunity dynamics, as it determines dispersal probabilities among lakes (Latini, 2005; Latini \& Petrere, 2007). Only the streams, and not the main river, were considered as potential dispersal routes among lakes, as they are the only closely connected to the first lakes where fish introductions took place in the region, from where invasive species have been spreading out (Latini, 2005).

\section{Analysis}

We tested for differences in native species composition among lake categories using Mantel's test (Legendre \& Legendre, 1998), specifically Mantel's correlation between the dissimilarity matrix and the grouping matrix (Manly, 2004). The grouping matrix contains "zeros" for pairs of lakes which pertain to the same lake category (lake status), and "ones" when they pertain to different categories. This analysis is generally applied to studies comparing biological communities (Legendre et al., 2005). Faunal dissimilarities among lakes were measured by the Bray-Curtis index (Magurran, 2004), calculated using species biomass in each lake (summed across all sample periods).

We used a linear regression to analyze the relationship between native species body size and biomass in lakes with piscivorous non-natives. The independent variable was mean standard length, and the dependent variable was the proportion of biomass of each native species which was contained in lakes with invasive piscivores. For instance, if the total biomass in the entire study of a given species is 10 $\mathrm{kg}$, and if its biomass summed along the three lakes with 


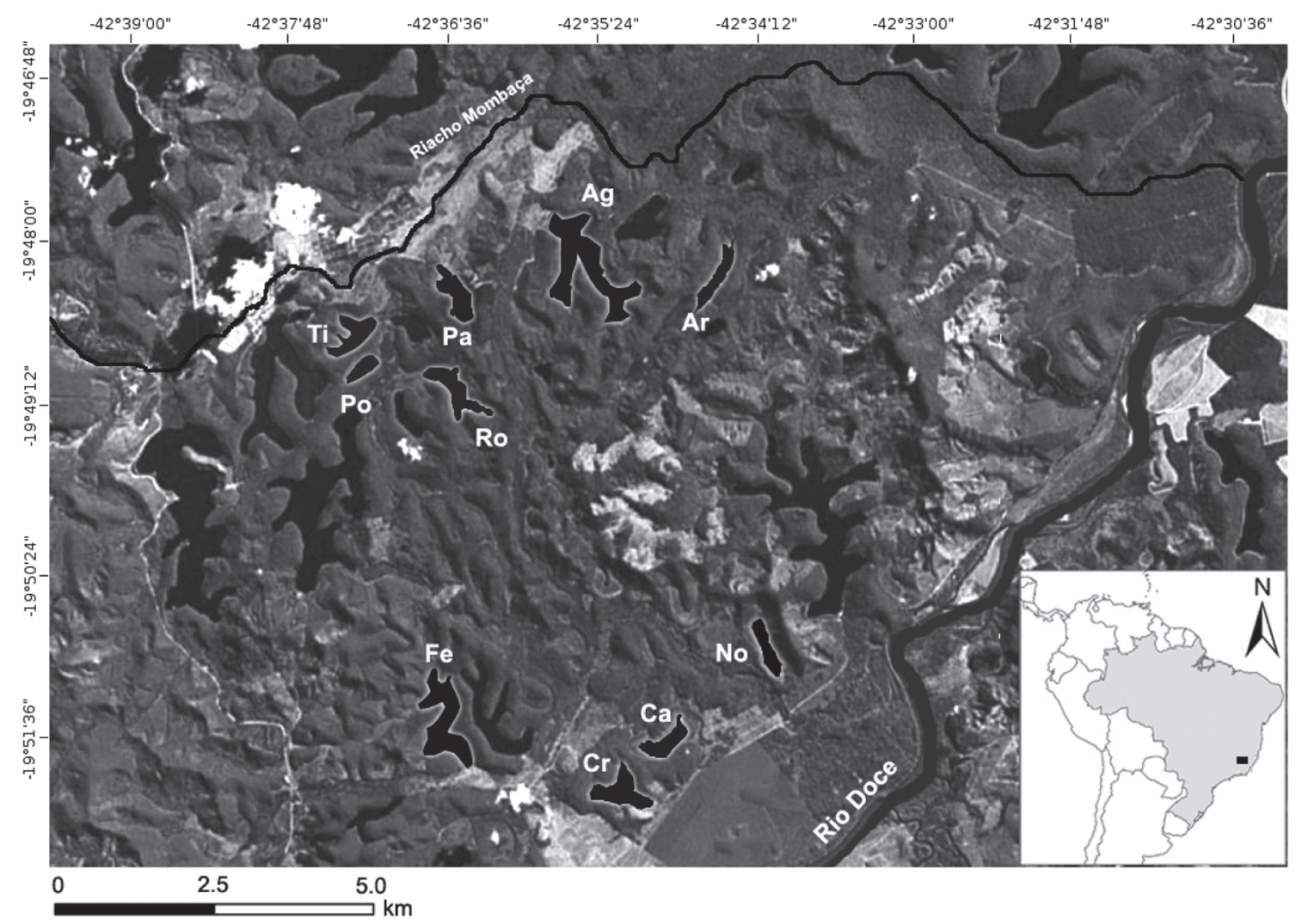

Fig. 1. Study region, indicating the ten sampled lakes. The lakes Capim $(\mathrm{Ca})$, Ferrugem $(\mathrm{Fe})$ and Nova (No) have only native fish species, lakes Crentes (Cr), Poço Redondo (Po), Romoalda (Ro), and Timburé (Ti) have non-piscivorous non-native fish species present, and lakes Águas Claras (Ag), Ariranha (Ar), and Palmeirinha (Pa) have non-native piscivores present.

invasive piscivores gives $3 \mathrm{~kg}$, so its measure of success, or aptitude for these lakes, is $0.3(30 \%)$. It is expected that as large is that proportion, the more adapted (or pre-adapted) is the species to the conditions imposed by those lakes, and then less susceptible should be this species to the predation exerted by the invasive piscivores. This analysis has the advantage of emphasizing the biogeographic pattern of species distributions.

Alternatively, we carried out another analysis emphasizing community pattern: instead of using species, we used the lakes as units, and the mean individual size (standard length of native species) in each lake as the dependent variable. This analysis allows a more rigorous assessment of the effect of non-native species, as we can now account for other environmental effects. To do so, we made an ANCOVA on the mean individual size on the lake having as independent variables: (i) the lake status, with three levels (natives only, occurrence of non-native nonpiscivores species, and occurrence of invasive piscivores species), (ii) the factors extracted from a Principal Component Analysis (PCA) with the abiotic variables.

Species richness was analyzed by decomposing gamma diversity (regional diversity) into the alpha and beta components (Magurran, 2004) for both spatial (among lakes) and temporal (among bimonthly samples) variation. For spatial comparisons, data were grouped across temporal sampling periods. For this analysis, alpha diversity represents the mean richness of individual lakes and beta diversity represents the faunal complementarity among them (or the spatial species turnover). For temporal comparisons, data were grouped across lakes for each time period, and alpha and beta diversity represent temporal richness and turnover, respectively. We also examined temporal aspects of alpha and beta diversity for each lake independently. For all approaches, beta diversity can be calculated as the difference between gamma diversity and alpha diversity, according to their additive relationship (Lande, 1996):

$$
\mathrm{S}_{\gamma}=\mathrm{S}_{\alpha}+\mathrm{S}_{\beta}
$$

where $\mathrm{S}_{\gamma}, \mathrm{S}_{\alpha}$ and $\mathrm{S}_{\beta}$ are the gamma, alpha (taking the mean richness along spatial or temporal component) and beta richness, respectively.

We compared the mean alpha richness among lake classes using a simple one-way ANOVA. To verify whether the proportion of alpha and beta components depends on lake category, we used ANCOVA with beta diversity as the dependent variable and mean alpha richness as the covariate. All analyses above were done considering only the composition of native species. They were repeated using several combinations of the PCA factors of environmental variables as covariates to control for.

The statistical analyses were carried out in Statistica 7, except for the Mantel tests, which were performed in Matlab 6.5 . 


\section{Results}

We collected 3202 specimens of 21 species (15 natives), totaling $175.30 \mathrm{~kg}$ (Table 1). Of that total, $37.61 \mathrm{~kg}(21.45 \%)$ was comprised by non-native species. The dominant species in the overall biomass was the native trahira Hoplias malabaricus (Bloch, 1794) with $39.86 \mathrm{~kg}(22.74 \%)$. Pygocentrus nattereri was the most abundant non-native with $17.20 \mathrm{~kg}$ (9.81\% of total biomass), and was the dominant species at one lake and the second dominant in the other two where it occurs (behind Prochilodus vimboides Kner, 1859, a cryptogenic, probably native species). The period with highest biomass captured was September 2002 (beginning of spring), with $41.65 \mathrm{~kg}(23.76 \%)$.

In general, the variability in species composition was higher among lakes than among different times in a year, as beta richness was dominated by the spatial dimension (Fig. 2a). The Mantel's test indicates significant differences of species composition among lake categories (observed correlation $\mathrm{r}=0.527, \mathrm{p}=0.001$ ). The differences persisted when we grouped lakes without non-natives with lakes with non-natives non-piscivores and compared it to lakes with invasive piscivores $(r=0.395, \mathrm{p}=0.029)$ and also when we compared lakes without non-natives with all lakes presenting any non-native $(\mathrm{r}=0.4665, \mathrm{p}=0.003)$. Thus, there are consistent differences among all three lake groups concerning their native fish assemblages.

Figure 3 shows clearly a gradient of affinities of native species to different lake types (from lakes without invaders to lakes with the greatest relative biomass of invaders, including piscivores). The lakes with piscivorous invaders are characterized by concentrating the biomasses of Prochilodus vimboides, Trachelyopterus striatulus (Steindachner, 1877) and Gymnotus gr. carapo Linnaeus, 1758 (species with relatively large size), but also Lycengraulis sp. The lakes without invaders depart from others by concentrating the biomasses of Cyphocharax gilbert (Quoy \& Gaimard, 1824), Moenkhausia doceana (Steindachner, 1877), Oligosarcus solitarius, Astyanax sp. and Australoheros facetus (Jenyns, 1842) (another cryptogenic species), which have relatively small body sizes.

The gradient of affinities, as suggested by inspection of Fig. 3, is indeed associated to body size. Smaller species have less affinity to lakes with invasive piscivores (Fig. 4), as confirmed by the linear regression analysis $\left(\mathrm{R}^{2}=0.443\right.$, $\left.\mathrm{F}_{1,13}=10.339, \mathrm{p}=0.007\right)$. This reinforces the hypothesis that the body size influences negatively the vulnerability to predation, if we assume that the invasive piscivores are really influencing the survivorship of native populations. The analysis is limited by the fact that some species are poorly represented in samples (some with only two individuals). This could make suspicious the biomass proportions used as dependent variable. Even so, it is improbable that the highly significant pattern could be due to chance alone. To verify the pattern consistency, we reanalyzed the data considering only those species represented by more than 10 individuals (which excluded four species: Crenicichla lacustris (Castelnau, 1855), Pachyurus adspersus Steindachner, 1879, G. gr. carapo and the Loricariidae species), and the result remains significant
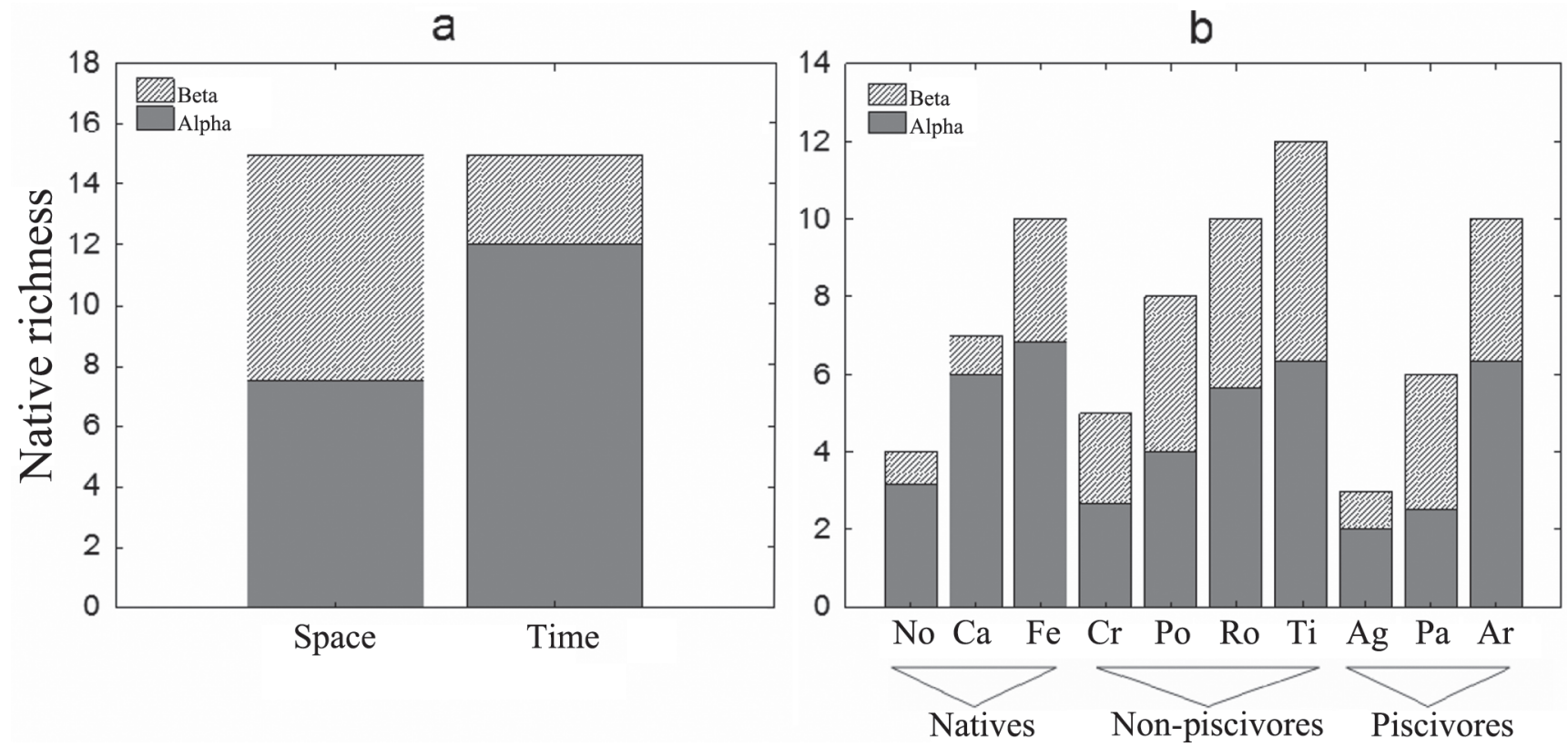

Fig. 2. Alpha (mean) and beta richness. a) Comparison among the temporal and spatial components of richness. b) Species richness for each lake. The alpha (mean) and beta richness were taken along the temporal component. Lake codes: No= Nova; $\mathrm{Ca}=$ Capim; $\mathrm{Fe}=$ Ferrugem; $\mathrm{Cr}=$ Crentes; $\mathrm{Po}=$ Poço Redondo; $\mathrm{Ro}=$ Romoalda $\mathrm{Ti}=$ Timburé; $\mathrm{Ag}=$ Águas Claras; $\mathrm{Pa}=$ Palmeirinha; $\mathrm{Ar}=$ Ariranha. "Natives" represents lakes without non-native species; "Non-piscivores" represents lakes with non-piscivorous non-native species; "Piscivores" represents lakes with invasive piscivorous species. 
Table 1. List of collected species, presenting size ranges (standard lengths), total abundances and biomasses. Non-native species are also identified.

\begin{tabular}{|c|c|c|c|c|}
\hline Species name & Non-native & Standard length $(\mathrm{cm})$ & Abundance & Biomass (kg) \\
\hline \multicolumn{5}{|l|}{ Order Characiformes } \\
\hline \multicolumn{5}{|l|}{ Family Anostomidae } \\
\hline Leporinus steindachneri Eigenmann, 1907 & & $8.6-34.0$ & 58 & 10.39 \\
\hline \multicolumn{5}{|l|}{ Family Characidae } \\
\hline Astyanax sp. & & $4.5-14.0$ & 1074 & 13.18 \\
\hline Moenkhausia doceana (Steindachner, 1877) & & $5.0-8.6$ & 373 & 2.78 \\
\hline Oligosarcus solitarius Menezes, 1987 & & $8.2-19.0$ & 343 & 9.35 \\
\hline Pygocentrus nattereri Kner, 1858 & $\mathrm{X}$ & $7.5-23.5$ & 110 & 17.20 \\
\hline \multicolumn{5}{|l|}{ Family Curimatidae } \\
\hline Cyphocharax gilbert (Quoy \& Gaimard, 1824) & & $6.8-18.0$ & 562 & 23.67 \\
\hline \multicolumn{5}{|l|}{ Family Erythrinidae } \\
\hline Hoplias malabaricus (Bloch, 1794) & & $10.5-37.0$ & 196 & 39.86 \\
\hline \multicolumn{5}{|l|}{ Family Prochilodontidae } \\
\hline Prochilodus vimboides Kner, 1859 & & $7.5-41.0$ & 58 & 24.22 \\
\hline \multicolumn{5}{|l|}{ Order Siluriformes } \\
\hline \multicolumn{5}{|l|}{ Family Auchenipteridae } \\
\hline Trachelyopterus striatulus (Steindachner, 1877) & & $10.0-19.7$ & 38 & 3.66 \\
\hline \multicolumn{5}{|l|}{ Family Callichthyidae } \\
\hline Hoplosternum littorale (Hancock, 1828) & $\mathrm{X}$ & $9.4-19.5$ & 125 & 14.15 \\
\hline \multicolumn{5}{|l|}{ Family Clariidae } \\
\hline Clarias gariepinus (Burchell, 1822) & $\mathrm{X}$ & $30.5-55.0$ & 3 & 3.17 \\
\hline Family Loricariidae & & $11.5-13.0$ & 2 & 0.08 \\
\hline \multicolumn{5}{|l|}{ Order Gymnotiformes } \\
\hline \multicolumn{5}{|l|}{ Family Gymnotidae } \\
\hline Gymnotus gr. carapo Linnaeus, 1758 & & $6.2-31.0$ & 9 & 0.85 \\
\hline \multicolumn{5}{|l|}{ Order Perciformes } \\
\hline \multicolumn{5}{|l|}{ Family Cichlidae } \\
\hline Astronotus ocellatus (Agassiz, 1831) & $\mathrm{X}$ & 13.5 & 1 & 0.15 \\
\hline Australoherus facetus (Jenyns, 1842) & & $5.0-7.8$ & 13 & 0.17 \\
\hline Cichla kelberi Kullander \& Ferreira, 2006 & $\mathrm{X}$ & $14.5-37.5$ & 8 & 2.90 \\
\hline Crenicichla lacustris (Castelnau, 1855) & & $11.3-22.0$ & 6 & 0.68 \\
\hline Geophagus brasiliensis (Quoy \& Gaimard, 1824) & & $5.4-18.0$ & 207 & 8.26 \\
\hline Oreochromis niloticus (Linnaeus, 1758) & $\mathrm{X}$ & 22.0 & 1 & 0.05 \\
\hline \multicolumn{5}{|l|}{ Family Sciaenidae } \\
\hline Pachyurus adspersus Steindachner, 1879 & & $21.5-22.5$ & 2 & 0.41 \\
\hline \multicolumn{5}{|l|}{ Order Clupeiformes } \\
\hline Family Engraulidae & & & & \\
\hline Lycengraulis sp. & & $6.5-15.0$ & 13 & 0.12 \\
\hline
\end{tabular}

$\left(\mathrm{R}^{2}=0.494 ; \mathrm{F}_{1,9}=8.802 ; \mathrm{p}=0.016\right)$. The pattern is also robust to the measure of length, remaining significant after using maximum standard length as independent variable $\left(\mathrm{R}^{2}=\right.$ $0.364, \mathrm{~F}_{1,13}=7.452, \mathrm{p}=0.017$, with all species, and $\mathrm{R}^{2}=0.442$, $\mathrm{F}_{1,9}=7.120, \mathrm{p}=0.026$, excluding the four rarest species).

The remaining analyses were made assuming the lake as the sampling unit, which allowed for the inclusion of environmental variables as covariates. The PCA was reasonably effective in concentrating the total variance of abiotic variables in the first two or three factors (Table 2). The cumulative explained variance was $53 \%, 77 \%$ and $95 \%$ for the first one, two and three factors respectively. The first factor is due mainly to lake size and oxygen concentration; the second is due to water turbidity, and the third due to the distance to drainage system.
The results from analyzing four dependent variables are summarized in Table 3. The main interest was in the lake status, so we carried out analyses to test its effect alone first. Then we introduced the PCA factors, one by time, and checked the results. By analyzing the effects of these factors separately (excluding lake status), we found that only the PCA factor 3 had significant influence on a dependent variable: the relative contribution of temporal beta richness (temporal species turnover). On the other hand, the lake status alone influenced significantly both the mean individual size and the relative contribution of temporal beta richness (Fig. 5).

Considering the last result, a planned contrast between lakes without non-natives and lakes with any non-native was significant: $F_{1,6}=11.386, p=0.015$, but there was no difference 


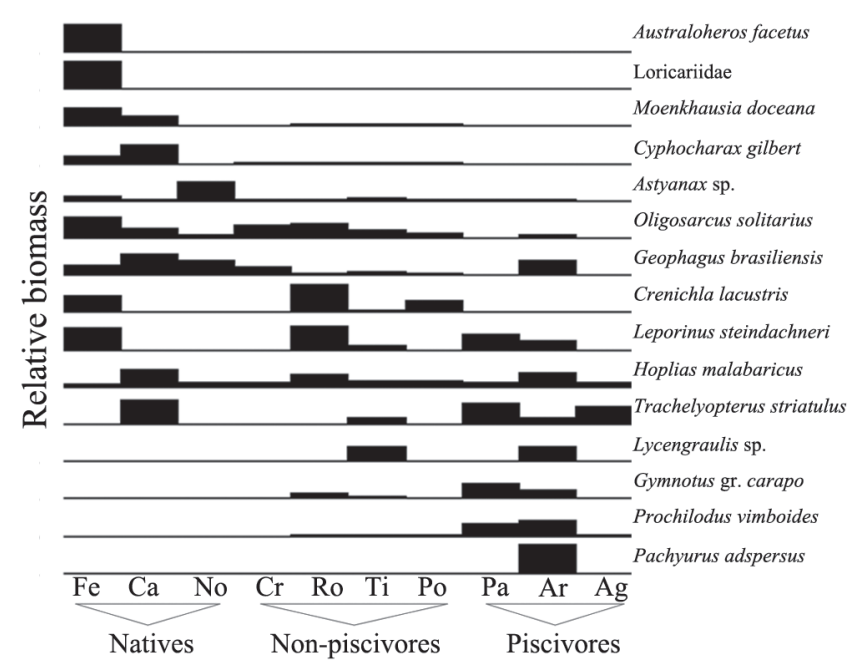

Fig. 3. Relative biomass of native species along a gradient of relative biomass of non-native species. From left to right, there is an increase in the relative biomass of non-native species (except for the first three which contains only native species and were ordered arbitrarily). Lake codes: $\mathrm{No}=\mathrm{Nova} ; \mathrm{Ca}=$ Capim $; \mathrm{Fe}=$ Ferrugem $; \mathrm{Cr}=$ Crentes $; \mathrm{Po}=$ Poço Redondo $; \mathrm{Ro}=$ Romoalda $; \mathrm{T}=$ Timburé $; \mathrm{Ag}=$ Águas Claras; $\mathrm{Pa}=$ Palmeirinha; $\mathrm{Ar}=$ Ariranha. "Natives" represents lakes without non-native species; "Non-piscivores" represents lakes with nonpiscivores non-native species; "Piscivores" represents lakes with non-native piscivorous species. The species were ordered arbitrarily, in such a way to make a gradient more visible. The relative biomass sum to $100 \%$ along each horizontal line that represents a species (the scale is not the same for every species).

between the two categories of lakes with non-natives (planned contrast: $F_{1,6}=1.065, p=0.342$ ). Taken together, these analyses illustrate that species turnover along a year is relatively lower in lakes without non-native species (Fig. 5). It can be noticed also by observing Fig. $2 b$, where the proportion of the beta component is visibly smaller in lakes with natives only. Nevertheless, the addition of either environmental factor precludes this effect, which turns to be no more significant.

The addition of environmental covariates did not have a so strong influence on the lake status effect when considering the mean individual size as dependent variable. The effect is still significant even after including the first two PCA factors (which accounts for $77 \%$ of environmental variability). In the first three analyses indicating significant status effect (Table 3), planned contrasts all point to a consistent pattern where the lakes with piscivorous non-natives have smaller mean individual size of native fishes than the other two lake types (Fig. 5).

After including the third PCA factor, the effect was no more significant. It has two possible reasons worth to mention here: (i) too few remaining degrees of freedom and (ii) nonindependence, or colinearity, among the PCA covariates and the lake status (Fig. 6). The third PCA factor is almost completely explained by the distance to drainage system (Table 2 ). This variable is strongly related to lake status, as can be

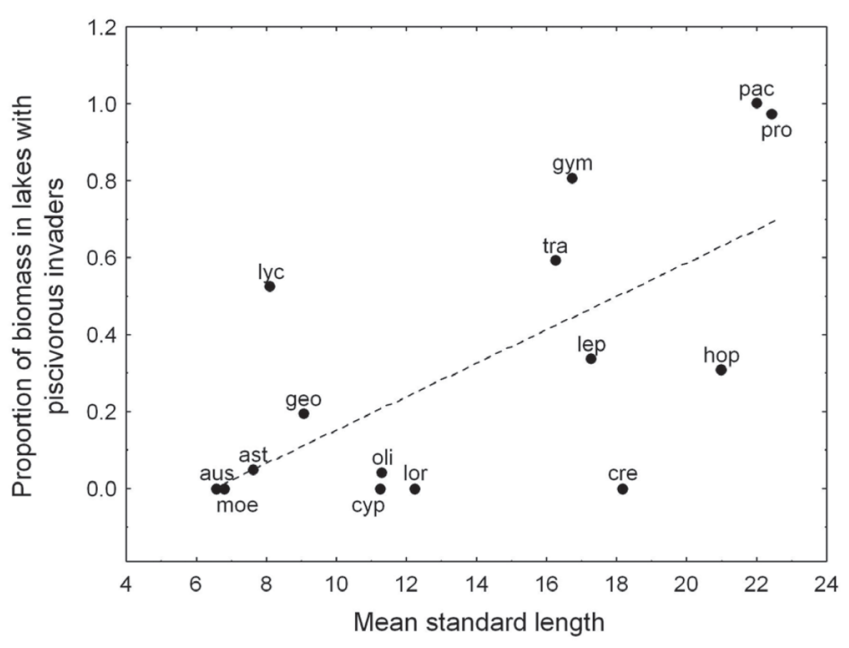

Fig. 4. Scatterplot of species body size (mean standard length) $v s$. a relative index of native affinity to lakes containing piscivorous invaders (the proportion of biomass of a given native species in lakes with piscivorous invaders). The estimated regression line is also presented $\left(\mathrm{Y}=0.044 * \mathrm{X}-0.279 ; \mathrm{R}^{2}=0.443 ; \mathrm{p}=0.007\right)$. Species codes: ast $=$ Astyanax $\mathrm{sp} . ;$ aus $=$ Australoheros facetus; cyp $=$ Cyphocharax gilbert; cre $=$ Crenicichla lacustris; geo $=$ Geophagus brasiliensis; gym = Gymnotus gr. carapo; hop = Hoplias malabaricus; lep = Leporinus steindachneri; lor $=$ Loricariidae (unidentified species); lyc $=$ Lycengraulis sp.; moe $=$ Moenkhausia doceana $;$ oli $=$ Oligosarcus solitarius $;$ pac $=$ Pachyurus adspersus $;$ pro $=$ Prochilodus vimboides; tra $=$ Trachelyopterus striatulus.

confirmed by a close inspection of Fig. 1, and also by the low tolerance values from the ANCOVA concerning the PCA factor 3 and lake status, one of them near $12 \%$. So we can say that the effect of lake status is partially due to the distance to the drainage system, but three results point to an accompanying predation effect on native assemblages: (i) the mean native individual size is significantly distinct only for lakes with invasive piscivores (as predicted by the hypothesis of differential vulnerability), while the distance to the drainage system, as well as any other environmental variable, is similar between the two categories of invaded lakes, being distinct only for lakes composed entirely by natives (which is consistent with the pattern of temporal species turnover); (ii) no environmental factor, included alone or combined with other(s), is significantly related to the mean size; and (iii) if included together with only the PCA factor 3, the lake status effect on mean size remains significant, which suggests that the degrees of freedom has some importance in our case.

\section{Discussion}

The results show that the lake categorization according to the occurrence of two major kinds of non-native species is significantly associated to the community structure of 
native fishes. Although the categorization carries an obvious distinction between trophic behaviors of nonnative fishes (piscivores $v s$. non-piscivores), and even with the statistical analysis pointing to a separate effect of lakes with piscivores on the mean native size, it must be emphasized that predation may not be necessarily the actual and only working mechanism. Lake connectivity has shown to be also related to the categorization we used. Then a first tentative to explain the patterns we detected must rely both on predation/competition theory and on metacommunity theory, which comprises the effects of dispersal limitation on spatially structured assemblages (Leibold et al., 2004). It is not within the scope of the present paper to speculate about every alternative hypothesis which could explain the same patterns. So the following discussion will be based on the assumption that such theories suffice to draw conclusions about the
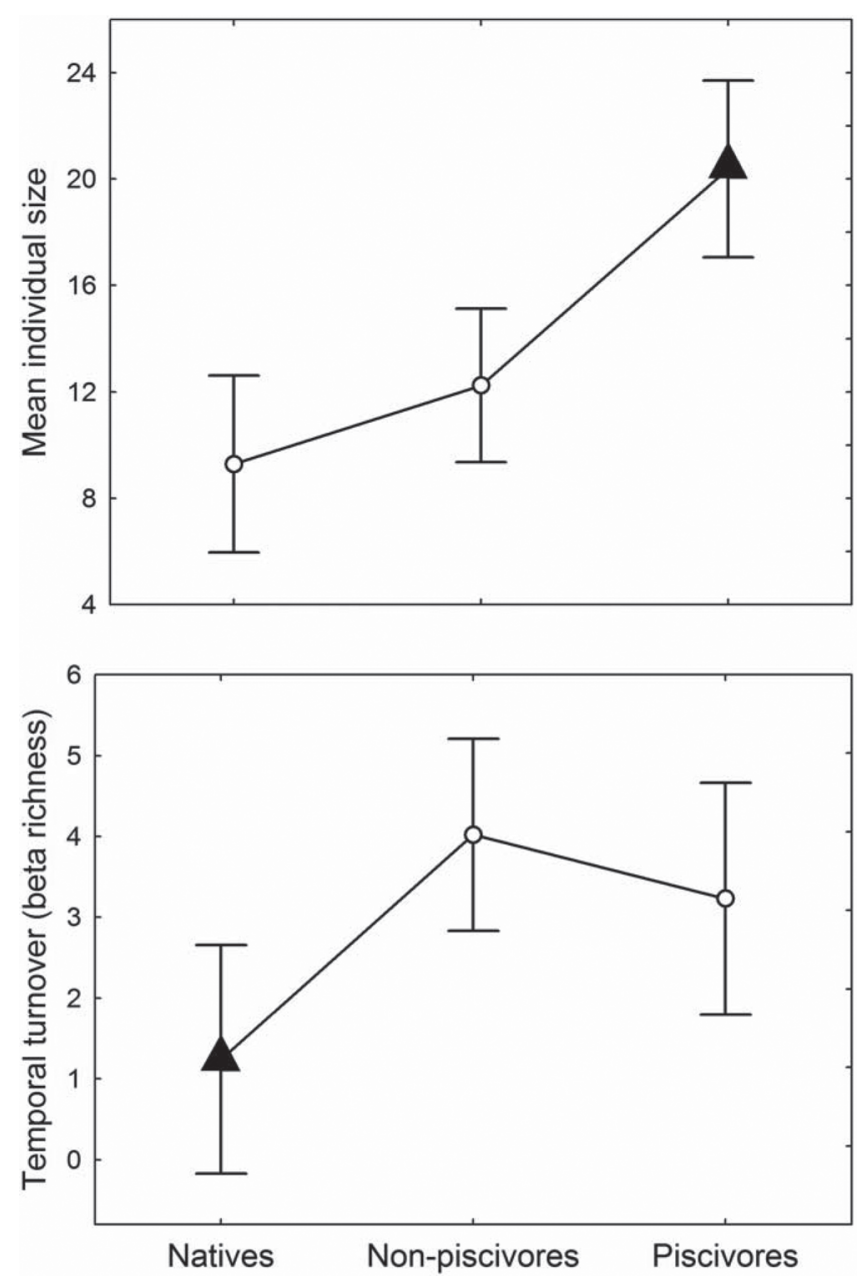

Fig. 5. Least-square means and $95 \%$ confidence intervals from ANCOVA of mean individual size and temporal turnover as related to the three lake categories. Different markers represent significantly different means as detected by planned contrasts with $5 \%$ significance level, first comparing lakes with any non-native species with those without them, and then comparing the two categories of lakes with non-natives (non-piscivores vs. piscivores). underlying mechanisms, which must be thought rather as a posteriori hypotheses. But other sources cannot be excluded, given the observational character and sampling size limitation of our collected data.
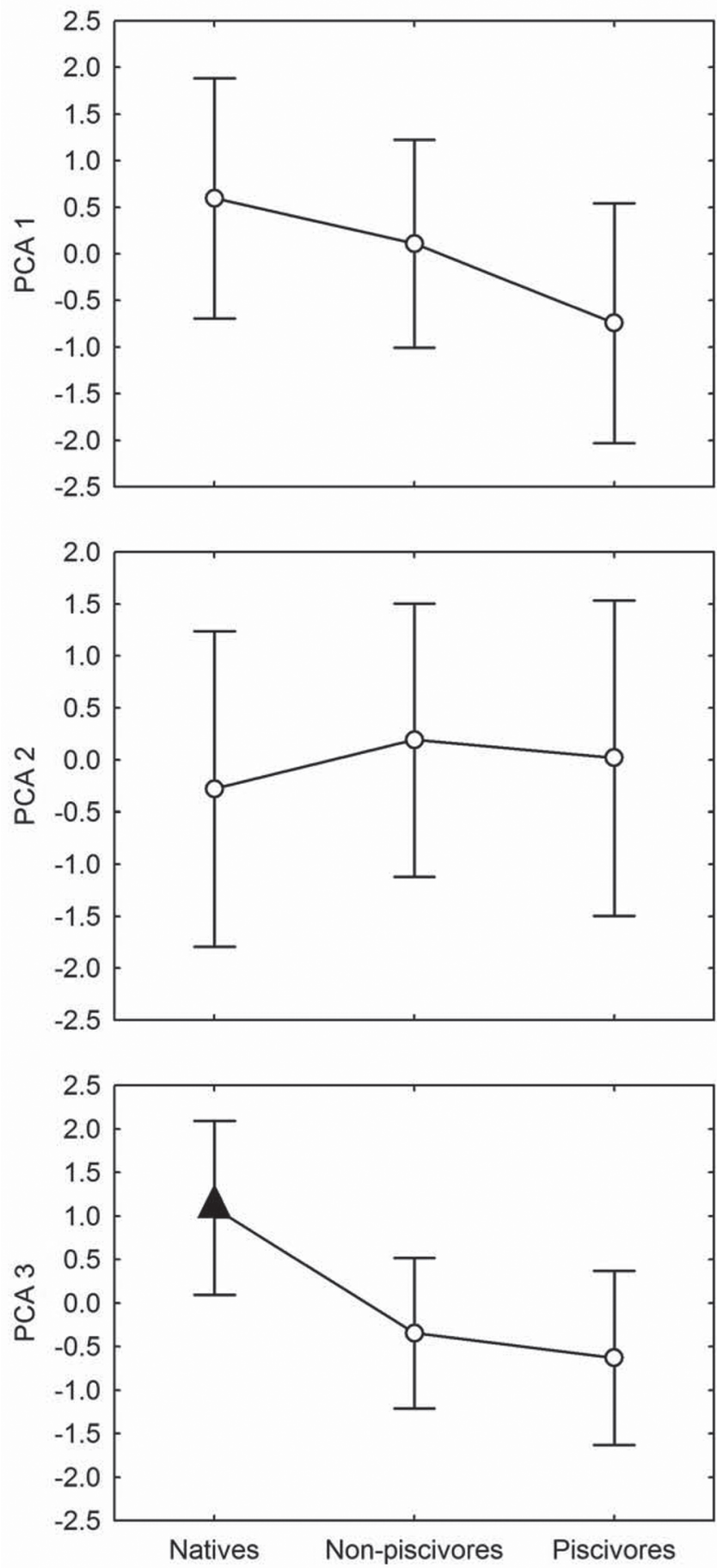

Fig. 6. Least-square means and $95 \%$ confidence intervals from ANCOVA of the first three environmental factors from PCA. Different markers represent significantly different means as detected by planned contrasts with $5 \%$ significance level, first comparing lakes with any non-native species with those without them, and then comparing the two categories of lakes with non-natives (non-piscivores $v s$. piscivores). 
In the lakes of the middle rio Doce, the most important native piscivore was the trahira Hoplias malabaricus, a solitary sit-and-wait predator that spends most of its time resting on the bottom of lake margins. The native fish populations are evolutionarily adapted to this kind of predator, but presumably do not present effective defenses against active predators like $P$. nattereri or $C$. kelberi. This may explain the supposed decimation of more vulnerable species in lakes were piscivores introductions took place.

According to the hypothesis of differential vulnerability, species that are more negatively affected by predation must have their biomass concentrated in lakes without invasive piscivorous. It is also expected that species indifferent to the presence of those invaders should have their biomass randomly distributed along lake types. However, some larger species, like Prochilodus vimboides, presented higher affinity to lakes with piscivorous invaders. If we are concerned purely with ecological interactions, one possible explanation is that the presence of piscivorous invaders inverted the competition dominance relationships inside lakes (Holt et al., 1994). It is plausible that larger and less vulnerable species were inferior competitively before the changes imposed by invasive fishes. In the absence of aggressive behaviour, or any kind of size-based interference among competing individuals, it is expected that smaller species do better in exploitative competition by their lower energetic requirements and also by their scaling relationship among metabolic and ingestion rates (Persson, 1985; Persson et al., 1998). This confers them a K-advantage (in mention to the carrying capacity of logistic growth model). In other words, they tend to present higher carrying capacities which may overcome the $\alpha$ advantage (in mention to the per capita effect in Lotka-Volterra competition model) generally associated to larger organisms (Persson, 1985). Thus, it is theoretically plausible that larger and less vulnerable species were inferior competitors under the local lake conditions before the changes imposed by invasive fishes.

After the introduction and establishment of piscivorous species in some lakes, the smaller native species may have turned to be strongly limited by predation, possibly liberating resources which previously limited the populations of larger and less vulnerable species. Thus, the population regulation which was before predominantly bottom-up could have became predominantly top-down (Herendeen, 2004), being the apparent competition (sensu Holt, 1977) the principal mechanism responsible to inversions in the dominance pattern (Holt et al., 1994). Such hypothetical reversal of limiting factors could explain why the species composition changed with lake type in a predictable way (smaller species

Table 2. Factor loadings from the Principal Component Analysis with five environmental variables of lakes.

\begin{tabular}{lccccc}
\hline Variables & Factor 1 & Factor 2 & Factor 3 & Factor 4 & Factor 5 \\
\hline Distance & 0.372 & 0.240 & $\mathbf{0 . 8 9 7}$ & -0.007 & 0.002 \\
Area & $\mathbf{- 0 . 9 2 8}$ & -0.289 & 0.180 & 0.118 & 0.098 \\
Perimeter & $\mathbf{- 0 . 9 0 7}$ & -0.335 & 0.206 & 0.115 & -0.096 \\
Oxygen & $\mathbf{- 0 . 8 3 1}$ & 0.417 & 0.025 & -0.368 & -0.002 \\
Turbidity & 0.352 & $\mathbf{- 0 . 8 9 3}$ & 0.117 & -0.254 & 0.004 \\
\% Explained & 52.737 & 24.483 & 17.865 & 4.540 & 0.376 \\
\hline
\end{tabular}

concentrated in lakes without psicivorous non-natives), while the overall diversity was not affected (Figs. 4-5, Table 3). In other words, we observed a change in species kinds, but not species number. If true, the expected effect of incomplete spreading of such invasive species would be increasing spatial species turnover in a regional (basin) scale.

A behavioral analogue effect of predation on the sizestructure of prey assemblage was recently found by Layman \& Winemiller (2004) in a species-rich neotropical river. Medium sized fishes dominated, in richness and abundance, the assemblages after large fish predators were excluded from the river sandbanks. The authors suggested an avoidance behavior by the medium sized fishes as the explanation to the observed pattern, as the experimental area was lower than the area daily used by the fishes. When the prey species is not evolutionary adapted to predator strategies, its arsenal of behavioral responses may be weekly sufficient to avoid its local extirpation and cascade effects may be responsible for its total failure in the local assemblage.

In the present paper, the temporal components of beta richness were measured at a short time scale of just one year. They do not represent species turnover in the classical sense of island biogeography (MacArthur \& Wilson, 1967) or in the context of macroevolution (McKinney \& Drake, 1998). Instead, they must be interpreted at most as a result of life-history variation among species in different lake types, along with seasonal variations in the age structure of populations or even in the degree of activity among species, which could be associated with resource availability and distribution along a year.

The species composition was more variable along time in lakes with non-native fishes. Independent from the causes of temporal variation in species composition, the results here presented have practical implications. Previous researches on the impacts of invasive fishes in the same region usually compare data from different years, showing the supposed exclusion of

Table 3. Results from ANOVAs/ANCOVAs with four dependent variables. Only the statistics concerning the effect of lake status are shown. The status effect "Alone" means that a one-way ANOVA was carried out; the status effect with any PCA factor means the addition of the respective factor(s) as covariate(s) in an ANCOVA. *Using the mean alpha richness as covariate in an ANCOVA.

\begin{tabular}{lllccc}
\hline \multirow{2}{*}{ Dependent variables } & \multicolumn{1}{c}{$\begin{array}{c}\text { Status } \\
\text { effect }\end{array}$} & $\mathrm{R}^{2}$ & $\begin{array}{c}\mathrm{df} \\
\text { (effect, error) }\end{array}$ & $\mathrm{F}$ & $\mathrm{p}$ \\
& Alone & $\mathbf{0 . 8 2 9}$ & $\mathbf{( 2 , 7 )}$ & $\mathbf{1 6 . 9 2 3} \mathbf{0 . 0 0 2}$ \\
Mean individual size & With PCA 1 & $\mathbf{0 . 8 3 0}$ & $\mathbf{( 2 , 6 )}$ & $\mathbf{9 . 6 7 9}$ & $\mathbf{0 . 0 1 3}$ \\
& With PCA 1,2 & $\mathbf{0 . 8 3 3}$ & $\mathbf{( 2 , 5 )}$ & $\mathbf{8 . 2 6 1}$ & $\mathbf{0 . 0 2 6}$ \\
& With PCA 1,2,3 & 0.839 & $(2,4)$ & 3.905 & 0.115 \\
& Alone & 0.138 & $(2,7)$ & 0.559 & 0.595 \\
Species richness & With PCA 1 & 0.175 & $(2,6)$ & 0.419 & 0.675 \\
& With PCA 1,2 & 0.404 & $(2,5)$ & 0.750 & 0.519 \\
& With PCA 1,2,3 & 0.656 & $(2,4)$ & 1.414 & 0.343 \\
Mean alpha richness & With PCA 1 & 0.172 & $(2,6)$ & 0.182 & 0.838 \\
& With PCA 1,2 & 0.450 & $(2,5)$ & 0.173 & 0.846 \\
& With PCA 1,2,3 & 0.600 & $(2,4)$ & 0.675 & 0.559 \\
Relative temporal & Wlone* & $\mathbf{0 . 7 6 3}$ & $(\mathbf{2 , 6 )}$ & $\mathbf{6 . 9 2 4}$ & $\mathbf{0 . 0 2 8}$ \\
turnover & With PCA 1 & 0.767 & $(2,5)$ & 5.738 & 0.051 \\
& With PCA 1,2 & 0.791 & $(2,4)$ & 4.605 & 0.092 \\
& With PCA 1,2,3 & 0.914 & $(2,3)$ & 2.491 & 0.230 \\
\hline
\end{tabular}


native species from some lakes (Sunaga \& Verani, 1991; Godinho, 1994). Nevertheless, some data were collected in quite different year periods, like June and December, and with a relatively small sampling effort (Sunaga \& Verani, 1985, 1987). The difference in year periods, by its own, should represent a problem of pseudoreplication (Hurlbert, 1984). What we show here is that there can be an additional and still not evaluated issue: the degree of variation in native species composition along a year is significantly higher in lakes with non-native fishes, which can generate a systematic bias in indicating false absences in such lakes depending on the sampling period. This problem is of major concern when the objective is to compare fish communities among lakes with and without invasive species.

The studied lakes compose a group of well defined habitat patches with limited dispersal among then. In analogy to the already well established metapopulation theory (Holyoak et al., 2005), our multi-species system must be contextualized to a metacommunity framework (Leibold et al., 2004; Holyoak et al., 2005b), which implies that the spatial configuration and dispersion rates among lakes may be of a paramount importance for explaining species compositions. Besides contributing to determine the occurrence of non-native fishes, the distance to the drainage system can also explain the pattern of species variability in time. Another study, carried out in a larger scale in the same region, showed that the incidence of non-native fishes among lakes is strongly dependent on the proximity to the closest stream (Latini et al., 2005; Latini \& Petrere, 2007), but not on any other environmental variable, just like the present study has also shown. It is very probable that the proximity of a given lake to a stream increases the probability of species exchange, which shall increase also the chances that this lake receives propagules of some non-native species. The same factor could be promoting the differences in compositional variability along year. During flooding, species migrating along river or streams can colonize the lakes connected to them, and so these lakes can show a stronger seasonal fluctuation in abundances of these species. The lakes Capim, Ferrugem and Nova, which do not present non-native fishes, are more isolated than the majority of lakes, and then may be less prone to compositional fluctuations caused by seasonal immigration. The consistency of such explanation is reinforced in our study by the matching patterns of temporal turnover and distance to the drainage system as related to lake status (Figs. 5-6), where lakes without non-natives are significantly distinct from the others concerning both variables, in the expected direction. Moreover, such isolation can be very restrictive to the presence of larger native species. Larger species, which have higher resource requirements, are more prone to extinction in isolated patches, without a sufficient immigration rate from the regional pool to allow for a rescue effect (Gotelli, 1991). It could apply to the largest species in our study, Prochilodus vimboides. On the other hand, we have also a small immigrating species, Lycengraulis sp., which presumably depends on the same dispersal corridors.

In summary, it is a necessary and usual conclusion that the segregation pattern observed among lakes is explained both by regional processes (i.e. dispersal heterogeneities) and local variables (i.e., presence/absence of non-native species of different types). These two factors are clearly linked, as the occurrence of non-native species depends on the spatial configuration of lakes in the same way as the native species. It remains to be seen at which degree such factors act synergistically in determining the observed segregation pattern. At this moment, our study provides suggestions for the contribution of both dispersal limitation (which determines at least non-native occurrences) and an additional predation effect (distinguishing lakes with piscivores from the others). We strongly recommend further studies on the region concerning these issues. More fish surveys could be done, trying to control for the confounding effects of lake status and distance to the drainage system, by choosing the remaining lakes without nonnatives as close as possible to the streams, and lakes with nonnatives as far as possible. Unfortunately, there are few lakes in the region which were not still invaded (Latini et al., 2004), which makes difficult to draw inferences from observational studies. Data on species diets can be valuable, providing a more realistic picture about the food web characteristics in those lakes and allowing inferring about interaction strengths between the most important species (Berlow et al., 2004). If the hypothesis of differential vulnerability is true, it is expected that the relative contribution of smaller species to the diet of main non-native piscivores should be larger than their relative biomasses. More detailed studies before and after the invasion by some species is still possible. Although experimental introductions are by no means recommendable, there is no guarantee that non-invaded lakes will remain in such a condition indefinitely. Assessing or monitoring the dynamics of still noninvaded lakes before the arriving of non-native species would provide a baseline source of information with great scientific value, so that unambiguous conclusions about posterior impacts could be drawn.

Given the potential harms of piscivorous invaders over local native fauna (Latini \& Petrere, 2004), and the framework provided by the metacommunity theory (Holyoak et al., 2005a), we expect that an eventual introduction of such invaders in the more isolated lakes to be more devasting than in their more connected counterparts. Lakes near the drainage system form a core of partially connected habitat patches. The spatial structuring of partially connected populations, together with temporal heterogeneities, can create spatio-temporal refuges to less capable species, by means of asynchronies in population dynamics (de Roos et al., 1991), diffusion limitation of predators or other natural enemies (Cuddington \& Yodzis, 2000), and scaling effects which diminishes interaction intensities (Chesson et al., 2005). All of these factors contribute to enhance coexistence (Chesson, 2000). Even if invaders have strong effects locally, immigration from more suitable lakes or even of residents from the streams can rescue previously extirpated or depleted native populations. The same may not work in more isolated lakes, which function as true islands, where many genetically and ecologically susceptible lineages are at serious risks in face of a future intentional or accidental introduction of widespread and generalist predators. 


\section{Acknowledgements}

This study was financially supported by the Fundo Nacional do Meio Ambiente (FNMA - convênio 80/2001), Ministério do Meio Ambiente, Governo Federal do Brasil and by the Conselho Nacional de Desenvolvimento Científico e Tecnológico (CNPq). The authors thank the Instituto Estadual de Florestas de Minas Gerais (IEF) and the Companhia Agrícola Florestal Santa Bárbara (CAF - Arcelor Mital) for logistic support. The instituto de Pesquisas da Mata Atlântica (IPEMA) was the executor institution of the Project "Ecologia de Peixes Exóticos do Médio Rio Doce" which originated this study. We also thank two anonymous reviewers and David Hoeinghaus for very helpful suggestions. Jorge Dergam kindly provided a picture of a Gymnotus specimen, and James Albert help identifying it.

\section{Literature Cited}

Berlow, E. L., A.-M. Neutel, J. E. Cohen, P. C. de Ruiter, B. Ebenman, M. C. Emmerson, J. W. Fox, V. A. A. Jansen, J. I. Jones, G. D. Kokkoris, D. O. Logofet, A. J. McKane, J. M. Montoya \& O. Petchey. 2004. Interaction strengths in food webs: issues and oportunities. Journal of Animal Ecology, 73: 585-598.

Chesson, P. 2000. Mechanisms of maintenance of species diversity. Annual Review of Ecology and Systematics, 31: 343-366.

Chesson, P., M. J. Donahue, B. A. Melbourne \& A. L. W. Sears. 2005. Scale transition theory for understanding mechanisms in metacommunities. Pp. 279-306. In: Holyoak, M., M. A. Leibold \& R. D. Holt (Eds.). Metacommunities: spatial dynamics and ecological communities. The University of Chicago Press.

Claessen, D., C. V. Oss, A. M. de Roos \& L. Persson. 2002. The impact of size-dependent predation on population dynamics and individual life history. Ecology, 83: 1660-1675.

Cohen, J. E., T. Jonsson \& S. R. Carpenter. 2003. Ecological community description using food web, species abundance, and body size. Proceedings of National Academy of Sciences of USA, 100: 1781-1786.

Cohen, J. E., S. L. Pimm, P. Yodzis \& J. Saldana. 1993. Body sizes of animal predators and animal prey in food webs. Journal of Animal Ecology, 62: 67-78.

Cuddington, K. M. \& P. Yodzis. 2000. Diffusion-limited predatorprey dynamics in euclidean environments: an allometric individual-based model. Theoretical Population, Biology, 58: 259278.

Drake, J. M. 2007. Parental investment and fecundity, but not brain size, are associated with establishment success in introduced fishes. Functional Ecology, 21: 963-968.

Drummond, G. M., C. S. Martins, A. B. M. Machado, F. A. Sebaio \& Y. Antonini. 2005. Biodiversidade em Minas Gerais: Um atlas para sua conservação. Fundação Biodiversitas, Belo Horizonte, 222p.

Fernando, C. H. 1991. Impacts of fish introductions in tropical Asia and America. Canadian Journal of Fisheries and Aquatic Sciences, 48: 24-32.

Godinho, A. L. 1994. The ecology of predator fish introductions: the case of Rio Doce valley lakes. Pp. 77-83. In: Pinto-Coelho, R. M., A. Giani \& E. C. von Sperling (Eds.). Ecology and human impact on lakes and reservoirs in Minas Gerais with special reference to future development and management strategies. SEGRAC VL - EN, 193p.
Gotelli, N. J. 1991. Metapopulation Models: The Rescue Effect, the Propagule Rain, and the Core-Satellite Hypothesis. American Naturalist, 138: 768-776.

Herendeen, R. A. 2004. Bottom-up and top-down effects in food chains depend on functional dependence: an explicit framework. Ecological Modelling, 171:21-33.

Holt, R. D. 1977. Predation, apparent competition and the structure of prey communities. Theoretical Population Biology, 12: 197-229.

Holt, R. D., J. Grover \& D. Tilman. 1994. Simple rules for interspecific dominance in systems with exploitative and apparent competition. The American Naturalist, 144: 741-771.

Holyoak, M., M. A. Leibold \& R. D. Holt. 2005a. Metacommunities: spatial dynamics and ecological communities. The University of Chicago Press, 513p.

Holyoak, M., M. A. Leibold, N. M. Mouquet, R. D. Holt \& M. F. Hoopes. 2005b. Metacommunities: a framework for large scale community ecology. Pp. 1-32. In: Holyoak, M., M. A. Leibold \& R. D. Holt (Eds.). Metacommunities: spatial dynamics and ecological communities. The University of Chicago Press, 513p.

Hurlbert, S. H. 1984. Pseudoreplication and the design of ecological field experiments. Ecological Monographs, 54: 187-211.

Jackson, D. A., P. R. Peres-Neto \& J. D. Olden. 2001. What controls who is where in freshwater fish communities - the roles of biotic, abiotic, and spatial factors. Canadian Journal of Fisheries and Aquatic Sciences, 58: 157-170.

Kitchell, J. F., D. E. Schindler, R. Ogutu-Ohwayo \& P. N. Reinthal. 1997. The nile perch in lake Victoria: interactions between predation and fisheries. Ecological Aplications, 7: 653-664.

Kolar, C. S. \& D. M. Lodge. 2002 Ecological Predictions and risk assessment for invasive fish in North America. Science, 298:1233-1236.

Lande, R. 1996. Statistics and partitioning of species diversity, and similarity among multiple communities. Oikos, 76: 5-13.

Latini, A. O. 2005. Inventário rápido e identificação de variáveis que limitam a dispersão de exóticos: um estudo sobre peixes no médio rio Doce. Unpublished Ph.D. Thesis, Universidade Estadual de Campinas, UNICAMP, Campinas, Brasil, 110p.

Latini, A. O., D. P. Lima-Júnior, H. C. Giacomini, R. O. Latini, D. C. Resende, H. M. V. Espírito-Santo, D. F. Barros \& T. L. Pereira. 2004. Invasive fishes in lakes of the Doce river basin (Brazil): range, new occurrences and conservation of native communities. Lundiana, 5: 135-142.

Latini, A. O., T. L. Pereira, R. O. Latini, H. C. Giacomini, D. P. Lima-Júnior, D. P. Oporto \& H. M. V. Espírito-Santo. 2005. Distribuição e efeitos de peixes exóticos sobre a ictiofauna nativa dos lagos do Médio Rio Doce, MG, Brasil. Pp. 99-118. In: Rocha, O., E. L. G. Espíndola, N. Fenerich-Verani, J. R. Verani \& A. C. Rietzler (Eds.). Espécies invasoras em águas doces: estudos de caso e propostas de manejo. Editora Universidade Federal de São Carlos, São Carlos, 416p.

Latini, A. O. \& M. Petrere, Jr. 2004. Reduction of a native fish fauna by invasive species: an example from Brazilian freshwater tropical lakes. Fisheries Management and Ecology, 11: 71-79.

Latini, A. O. \& M. Petrere, Jr. 2007. Which factors determine nonnative fish range. A study on red piranha Pygocentrus nattereri (Kner 1858) introduced in Brazilian tropical lakes. Pp. 415-422. In: Gherardi, F. (Ed.). Biological Invaders in Inland Waters: Profiles, Distribution, and Threats, Vol. 2. Book Series Invading Nature - Springer Series in Invasion Ecology. Springer, Amsterdam.

Layman, C. A. \& K. O. Winemiller. 2004. Size-based responses of prey to piscivore exclusion in a species-rich neotropical river. Ecology, 85: 1311-1320. 
Layman, C. A., K. O. Winemiller, D. A. Arrington \& D. B. Jepsen. 2005. Body size and trophic position in a diverse tropical food web. Ecology, 86: 2530-2535.

Legendre, P., D. Borcard \& P. R. Peres-Neto. 2005. Analyzing beta diversity: partitioning the spatial variation of community composition data. Ecological Monographs, 75: 435-450.

Legendre, P. \& L. Legendre. 1998. Numerical Ecology., 2nd edn. Elsevier, Amsterdan.

Leibold, M. A., M. Holyoak, N. Mouquet, P. Amarasekare, J. M. Chase, M. F. Hoopes, R. D. Holt, J. B. Shurin, R. Law, D. Tilman, M. Loreau \& A. Gonzalez. 2004. The metacommunity concept: a framework for multi-scale community ecology. Ecology Letters, 7: 601-613.

Leibold, M.A., R. D. Holt \& M. Holyoak. 2005. Adaptive and coadaptive dynamics in metacommunities: tracking environmental change at different spatial scales. Pp. 439-464. In: Holyoak, M., M. A. Leibold \& R. D. Holt (Eds.). Metacommunities: spatial dynamics and ecological communities. The University of Chicago Press.

Lockwood, J. L., M. F. Hoopes \& M. P. Marchetti. 2007. Invasion Ecology. Blackwell Publishing.

MacArthur, R. H. \& E. O.Wilson. 1967. The Theory of Island Biogeography. Princeton University Press, Princeton, 224p.

Mack, R. N., D. Simberloff, W. M. Lonsdale, H. Evans, M. Clout \& F. A. Bazzaz. 2000. Biotic invasions: cause, epidemiology, global consequences and control. Ecological Applications, 10: 689-710.

Magurran,A. E. 2004. Measuring biological diversity. Blackwell Science Ltd.

Manly, B. F. J. 2004. Randomization, bootstrap and Monte Carlo methods in Biology. University of Otago, Otago, New Zeland.

de Marco, P. Jr. 1999. Invasion by the introduced aquatic snail Melanoides tuberculata (Müller, 1774) (Gastropoda: Prosobranchia: Thiaridae) of the Rio Doce State Park, Minas Gerais, Brazil. Studies on Neotropical Fauna and Environment, 34(3): 186-189.

McKinney, M. L. \& J. A. Drake. 1998. Biodiversity dynamics: turnover of populations, taxa and communities. Columbia University Press, 552p.

McKinney, M. L. \& J. L. Lockwood. 1999. Biotic homogenization: a few winners replacing many losers in the next mass extinction. Trends in Ecology and Evolution, 14: 450-453.

McPeek, M. A. 1996. Trade-offs, food web structure, and the coexistence of habitat specialists and generalists. The American Naturalist, 148: 124-138.

Mittelbach, G. G. \& L. Persson. 1998. The ontogeny of piscivory and its ecological consequences. Canadian Journal of Fisheries and Aquatic Sciences, 55: 1454-1465.

Morton, D. \& R. Law. 1997. Regional species pools and the assembly of local ecological communities. Journal of Theoretical Biology, 187:321-331.

Moyle, P. B. \& T. Light. 1996. Biological invasions of freshwater: empirical rules and assembly theory. Biological Conservation, 78: 149-161.

Myers, N., R. A. Mittermeier, C. G. Mittermeier, G. A. B. Fonseca \& J. Kent. 2000. Biodiversity hotspots for conservation priorities. Nature, 403: 853-858.

Nimer, E. 1989. Climatologia do Brasil. IBGE, Rio de Janeiro.

Olden, J. D. 2006. Biotic homogenization: a new research agenda for conservation biogeography. Journal of Biogeography, 33: 2027-2039.

Olden, J. D., N. L. Poff, M. R. Douglas, M. E. Douglas \& K. D. Fausch. 2004. Ecological and evolutionary consequences of biotic homogenization. Trends in Ecology and Evolution, 19: 18-23.

Persson, L. 1985. Asymetrical competition: are larger animals competitively superior? The American Naturalist, 126: 261-266.

Persson, L., K. Leonardsson, A. M. de Roos, M. Gyllenberg \& B. Christensen. 1998. Ontogenetic scaling of foraging rates and the dynamics of a size-structured consumer-resource model. Theoretical Population Biology, 54: 270-293.
Pimentel, D., S. McNair, J. Janecka, J. Wightam, C. Simmonds, C. O'Connell, R. Wong, L. Russel, J. Zern, T. Aquino \& T. Tsomond. 2001. Economic and environmental threats of invasive plant, animal, and microbe invasion. Agriculture, Ecosystems and Environment, 84: 1-20.

Rahel, F. J. 2002. Homogenization of freshwater faunas. Annual Review of Ecology and Systematics, 33: 291-315.

Reis, R. E. 1997. Revision of the neotropical catfish genus Hoplosternum (Ostariophysi: Siluriformes: Callichthyidae), with the description of two new genera and three new species. Ichthyological Exploration of Freshwaters, 7: 299-326.

de Roos, A. M., E. McCauley \& W. G. Wilson. 1991. Mobility versus density-limited predator-prey dynamics on different spatial scales. Proceedings of the Royal Society of London B, 246: 117-122.

Rosenzweig, M. L. 1995. Species diversity in space and time, Cambridge University Press, Cambridge.

Sih,A., P. Crowley, M. McPeek, J.Petranka \& K. Strohmeier. 1985. Predation, Competition, and prey communities: A review of field experiments. Annual Review of Ecology and Systematics, 16: 269-311.

Simberloff, D. \& B. Von Holle. 1999. Positive interactions of nonindigenous species: invasional meltdown? Biological Invasions, 1:21-32.

Sinclair, A. R. E., S. Mduma \& J. S. Brashares. 2003. Patterns of predation in a diverse predator-prey system. Nature, 425: 288-290.

Sunaga, T. \& J. R. Verani. 1985. Preliminary report of comparative study on fish community of the Rio Doce Valley lakes. Pp. 167-174. In: Saijo, Y. \& J. G. C. P. Tundisi (Eds.). Limnological studies in Rio Doce Valley lakes and Pantanal wetland, Brazil. Nagoya University, 187p.

Sunaga, T. \& J. R. Verani. 1987. Second report of comparative study on fish community of the Rio Doce Valley lakes. Pp. 129-135. In: Saijo, Y. \& J. G. C. P. Tundisi (Eds.). Limnological studies in Rio Doce Valley lakes and Pantanal wetland, Brazil. Nagoya University, 187p.

Sunaga, T. \& J. R. Verani. 1991. The fish communities of the lakes in Rio Doce Valley, Northeast, Brazil. Verhandlungen der internationalen Vereinigung für, 24:2563-2566.

Thorp, J. H. \& M. L. Cothran. 1984. Regulation of freshwater community structure at multiple intensities of dragonfly predation. Ecology, 65:1546-1555.

Tundisi, J. G. \& M. R. M. de Meis. 1985. Geomorphology and limnological processes at the Middle Rio Doce Valley. Pp 11-17. In: Saijo, Y. \& J.G.C.P. Tundisi (Eds.). Limnological studies in Rio Doce Valley lakes and Pantanal wetland, Brazil. Nagoya University.

Vono, V. \& F. A. R. Barbosa. 2001. Habitats and littoral zone fish community structure of two natural lakes in southeast Brazil. Environmental Biology of Fishes, 61(4): 371-379.

Wellborn, G. A., D. K. Skelly \& E. E. Werner. 1996. Mechanisms creating community structure across a freshwater habitat gradient. Annual Review of Ecology and Systematics, 27: 337-363.

Woodward, G., B. Ebenman, M. C. Emmerson, J. M. Montoya, J. M. Olesen, A. Valido \& P. H. Warren. 2005. Body size in ecological networks. Trends in Ecology and Evolution, 20: 402-409.

Woodward, G. \& A. G. Hildrew. 2002. Body size determinants of niche overlap and intraguild predation within a complex food web. Journal of Animal Ecology, 71: 1063-1074.

Wooton R. J. 1992. Fish ecology. New York, Blackie.

Zaret, T. M. 1972. Predator-prey interacion in a tropical lacustrine ecosystem. Ecology, 53: 248-257.

Zaret, T. M. \& R. T. Paine. 1973. Species introductions in a tropical lake. Science, 182: 449-455.

Accepted September 10, 2010 Published March 31, 2011 